\title{
Pteridophytes of Moorea, French Polynesia, with a New Species, Tmesipteris gracilis (Psilotaceae) ${ }^{1}$
}

\author{
A. G. Murdock ${ }^{2}$ and A. R. Smith ${ }^{3}$
}

\begin{abstract}
We examined collections of pteridophytes from Moorea and others of the Society Islands, as well as literature relevant to the pteridophytes of Polynesia. This resulted in a list of species known to occur on Moorea, along with a list of species reported for Moorea but lacking voucher specimens, and a list of species perhaps to be found on Moorea based on collections from nearby Tahiti and adjacent islands in the archipelago, at suitable elevations. We include habitat, locality, and appropriate taxonomic commentary for each known species. A new species in the family Psilotaceae, Tmesipteris gracilis Chinnock, is described from the Society and Marquesas Islands. We also include a discussion of pteridophyte collection history on Moorea and biogeographic notes for species on the island.
\end{abstract}

Of The Society Islands, Tahiti is the best known and most heavily collected botanically. Moorea, Tahiti's closest neighbor and second highest island in the archipelago, has received relatively little attention, despite the fact that the stretch of water separating the two islands is only $14.5 \mathrm{~km}$ wide. Moorea also has sufficient elevation at points for there to be small areas of high-elevation cloud forest, the factor that makes Tahiti's high-elevation flora very rich. Moorea's highest peak, Mt. Tohiea $(1207 \mathrm{~m})$, as well as some of the lower peaks, are so treacherous that collection is difficult to impossible in some of the higher reaches of the island. Moorea also has the unique plant habitat of reef islands (motu), one of which served as the site for Joseph Banks' observations of the transit of Venus on the first voyage of Captain Cook.

${ }^{1}$ Manuscript accepted 4 November 2002.

${ }^{2}$ Department of Integrative Biology, 3060 Valley Life Sciences Bldg. 3140, University of California, Berkeley, California 94720-3140 (E-mail: murdock@ uclink. berkeley.edu).

${ }^{3}$ University Herbarium, 1001 Valley Life Sciences Bldg. 2465, University of California, Berkeley, California 94720-2465 (E-mail: arsmith@uclink4.berkeley.edu).

Pacific Science (2003), vol. 57, no. 3:253-265

(C) 2003 by University of Hawai' $i$ Press

All rights reserved
Relatively little has been published on the pteridophyte flora of the Society Islands. Copeland's Pteridophytes of the Society Islands (1932) is the most comprehensive but contains relatively little information on range. Furthermore, taxonomic revisions over the past 70 yrs have rendered that work out of date. Maxon's Report upon a collection of ferns from Tabiti (1924) is cursory and deals only with one collecting trip to Tahiti. The pteridophyte section of Brown's Flora of southeastern Polynesia (1931-1935) is brief and barely touches the Society Island flora. Drake del Castillo's Flore de la Polynésie Française (1893) is quite detailed but is also nearly useless because of numerous nomenclatural and taxonomic changes; moreover, Drake del Castillo himself never actually visited French Polynesia. Robert Robertson's Catalogue des plantes vasculaires de la Polynésie Française (1952) serves as a checklist compilation of Copeland (1932) and Drake del Castillo (1893) but contains scant new information.

The presence of the University of California at Berkeley's Richard B. Gump South Pacific Biological Research Station on Moorea has dramatically increased the number of plant collections on Moorea in recent years. These recent collections, coupled with a few important collections in the past, have made it possible to compile a list of pteridophytes known to be on Moorea. This list contains 72 species known with certainty 
from Moorea. In contrast, Tahiti has roughly 200 species of pteridophytes, mostly due to its higher elevation, nearly $2300 \mathrm{~m}$. There is still the possibility that more species will be found on Moorea in some of the less-accessible areas. Because of this possibility, two additional lists have been included: a list of eight species reported from Moorea but lacking voucher specimens, insofar as we have been able to determine; and a list of 19 additional species known to occur on one or often more other islands in the archipelago at elevations below $1000 \mathrm{~m}$ and thus quite possibly also on Moorea. A key to the Moorean species of pteridophytes is available by request from A.G.M.

In the course of the research for this paper, we uncovered a species of Tmesipteris, also referenced in Chinnock (1976), endemic to the Society and Marquesas Islands that has not been described previously. This species, Tmesipteris gracilis Chinnock, n. sp., is described in the Appendix by Robert J. Chinnock.

\section{Collectors}

As represented by specimens in the herbarium at University of California (UC), Berkeley, there have been three individuals responsible for collecting most of the pteridophytes on Moorea: Martin L. Grant, Howard M. Smith, and Patricia Sánchez Baracaldo. Grant spent about 10 months in the Society Islands in 1930-1931, principally on Tahiti, but five days on Moorea (17-21 February 1931), as well as short trips to several other of the Society Islands (Bora Bora, Huahine, Raiatea, Tahaa, Mehetia, and Tupai) (D. Grant 1986). At the time, he was supported by a fellowship from Yale University, while conducting botanical studies under the auspices of the Bernice P. Bishop Museum (BISH) in Hawai'i. These studies ultimately resulted in a dissertation on the dicotyledons of the Society Islands (M. L. Grant 1936). Grant collected approximately 25 pteridophytes on Moorea, but was unable to visit the highest and wettest sites on the islands, which are still relatively inaccessible. The first set of Grant's collections is de- posited in BISH, and additional relatively complete sets of the pteridophytes are in UC and IsTc. When he returned from Tahiti to the United States, Grant passed through San Francisco and UC, Berkeley, spending time in the herbarium there with staff and faculty members, including E. B. Copeland, then actively studying ferns of Asia and the Pacific.

Howard M. Smith, from the University of Richmond in Richmond, Virginia, made ca. 20 collections of pteridophytes on Moorea between 8 May and 6 August 1967. Smith and F. Raymond Fosberg edited and published Grant's unfinished Partial flora of the Society Islands: Ericaceae to Apocynaceae (Grant et al. 1974), wherein Smith, as a biological historian, added a lengthy history of plant collection in the Pacific. Most of his collections were seen and identified by Warren $H$. Wagner Jr., at the University of Michigan.

The most important recent collector of ferns on the island has been Patricia Sánchez Baracaldo, a graduate student in Integrative Biology at UC, Berkeley, who completed her $\mathrm{Ph} . \mathrm{D}$. dissertation on the genus famesonia at Berkeley in 2000. From 26 September to 8 November 1996 she made ca. 55 collections of pteridophytes on Moorea. The first set of these is in UC and additional sets will be sent to PAP, BISH, and NY. Sánchez Baracaldo's collections were made during her participation in a 10-week course at the Gump field station. Before and after that time, several additional collections have been made by the students and instructors of the annually given Moorea course (e.g., Brent Mishler, 21 October 1994, various collections, and Sharifa Gulamhussein [2000], who collected Tricbomanes spp. extensively), and these collections are also deposited in Uc.

Other collectors known to us who have made collections of ferns on Moorea are as follows: Ernest H. Quayle (5 November 1921; four collections seen), whose collections from Pacific islands are also deposited especially in BISH; Lawrence H. MacDaniels (1927), whose collections from Polynesia are deposited especially in A and вISH; Hugh S. McKee (September 1955), whose collections from Pacific islands are deposited especially in $\mathrm{E}, \mathrm{Nsw}$, and Us; F. Raymond Fosberg, who 


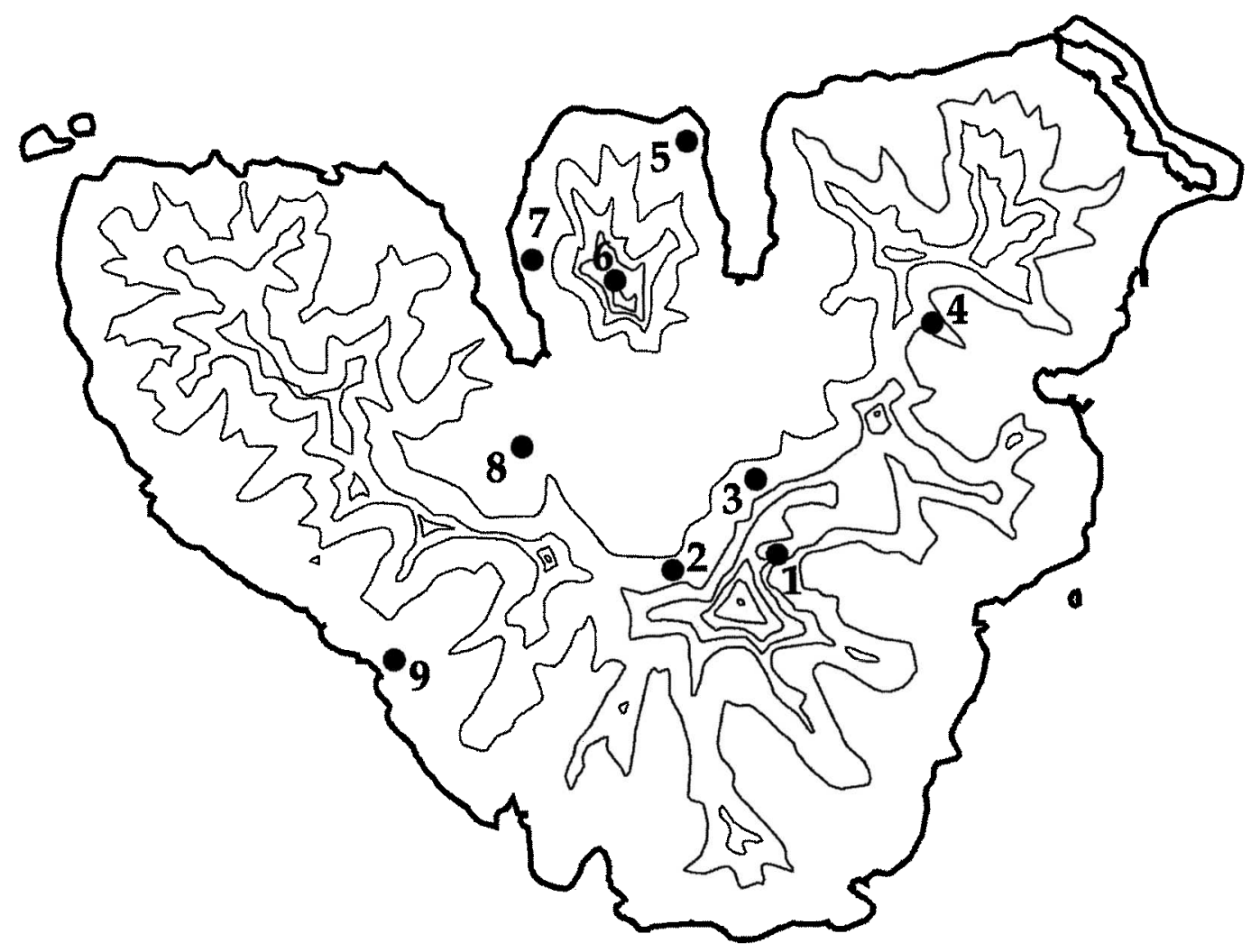

Figure 1. Moorea, with 200-m contour lines and approximate major collection locations: site 1, District of Afareaitu, high-elevation ridge of $\mathrm{Mt}$. Tohica; site 2, Belvedere, beginning of cloud forest, trail to Three Coconuts Pass; site 3, near Partula enclosure, tropical rain forest, dominated by Angiopteris; site 4, Vaiare, high-elevation ridge; site 5, UC Berkeley Gump Research Station; site 6, NW ridge of Mt. Rotui, high elevation; site 7, Marimari Kellum's property, western side of $\mathrm{Mt}$. Rotui; site 8, Lower Opunohu Valley; site 9, $\mathrm{Ha}^{\circ}$ apiti, sea level.

collected on Moorea multiple times over the course of his career, whose collections are deposited at вisн and us; and Jacques Florence (1982-1994), whose collections are deposited at $\mathrm{BISH}$, US, $\mathrm{P}$, and PAP as part of ongoing work on a multivolume flora of French Polynesia.

\section{PTERIDOPHYTES OF MOOREA}

The species known to be on Moorea are listed below alphabetically by family and genus, with salient synonymy (we list only those synonyms appearing in recent literature and do not list basionyms for each species), collection notes and locations (see Figure 1), and brief habitat descriptions where possible. It is our hope that this list can be used not simply as a reference on the pteridophytes of Moorea, but also as a list of species one would expect to find throughout French Polynesia. We refrain from citing numerous obsolete synonyms and basionyms when those names are not in recent use or unlikely to be used by current or future authors. Other than specifically cited floras, we found the recent fern volume of the Flora of Australia (McCarthy 1998) particularly useful for its discussion of nomenclatural problems and taxonomy.

Of the 72 species of pteridophytes known from Moorea, most are widespread throughout Polynesia and beyond. This is not sur- 
prising, given the relatively short geological history of Moorea, its close proximity to a larger and more topographically diverse landmass (Tahiti), and the pattern of prevailing winds in the southern Pacific. Four species on Moorea appear to be pantropical: Acrostichum aureum, Lycopodiella cernua, Opbioglossum reticulatum, and Psilotum nudum. Twenty-four are widespread throughout Polynesia, Melanesia, and Malesia, and some of these species extend into Micronesia, Australasia, continental Southeast Asia (e.g., Vietnam, China), and India; examples include Antrophyum plantagineum, A. reticulatum, Arachniodes aristata, Blecbnum orientale, Microsorum commutatum, $M$. membranifolium, Ophioglossum pendulum, and Trichomanes tabitense. Nine species extend through this same area and in addition into Madagascar and Africa; these are Adiantum hispidulum, Asplenium caudatum, Belvisia spicata, Dicranopteris linearis, Huperzia pblegmaria, Microsorum punctatum, Pteris tripartita, Scbizaea dichotoma, and Trichomanes bipunctatum.

We regard only eight species and one hybrid as endemic to the Society Islands, and these include Diplazium ellipticum, D. grantii, Lomagramma tabitensis, Microlepia scaberula, Microsorum $\times$ maximum, Prosaptia subnuda, Selaginella banksii, Tectaria tahitensis, and Trichomanes societense. However, some of these species are only dubiously distinct from more wide-ranging congeners (e.g., T. societense is very closely related to, and doubtfully different from, the widespread $T$. apiifolium C. Presl, occurring throughout Malesia and Polynesia). There are no endemic pteridophyte species known from Moorea.

Eleven species of pteridophytes occurring on Moorea are essentially restricted to Polynesia and Fiji, and these are Alsopbila tabitensis, Asplenium gibberosum, Blechnum raiateense, Ctenitis sciaphila, Ctenopteris purpurascens, Diplazium harpeodes, Lindsaea propinqua, Lomariopsis brackenridgei, Pyrrosia serpens (reported also from Norfolk Island), Spbaerostephanos subpectinatus, and Tmesipteris gracilis; the last two of these are known only from the Marquesas Islands, outside the Society Islands. Nine species extend throughout Polynesia and into Melanesia and Australasia, and these include Asplenium australasicum, Bolbitis lonchopbora, Lygodium reticulatum, Marattia salicina, Microsorum grossum, Pteris comans, Sphaeropteris medullaris, Teratopbyllum wilkesianum, and Trichomanes dentatum.

Five species are introduced and naturalized on Moorea, including Adiantum raddianum, A. trapeziforme, Nepbrolepis cordifolia, N. exaltata, and Pityrogramma calomelanos. All of these are native to, and widely distributed in, the New World tropics. One species, Marsilea polycarpa, is known only from the Neotropics and the Society Islands (Johnson 1986), but it has been suggested that this species is truly native in Moorea and not recently introduced (see Copeland [1932], who cited an 1834 collection from the area). Several widespread, weedy ferns that are naturalized in many parts of the world have not yet been found on Moorea but are to be expected (e.g., Christella dentata and Macrothelypteris torresiana).

\section{Aspleniaceae}

Asplenium australasicum (J. Sm.) Hook. Bird's-nest fern

Neottopteris australasica J. Sm.; Thamnopteris australasicum (J. Sm.) T. Moore; Holttum (1974).

Epiphytic at middle to high elevations; in rain forests, generally in high tree forks.

Sáncbez B. 127 (UC): Site 3.

Asplenium nidus L. has been attributed to Moorea by several authors, but specimens so identified have proven to be $A$. australasicum, which is distinguished by a sharply angular midrib at the blade base, abaxially (rounded in A. nidus).

Asplenium caudatum G. Forst. Asplenum borridum Kaulf.

Epiphytic or lithophytic.

Florence 8355 (BISH): Site 1, on Ilex.

Asplenium gibberosum (G. Forst.) Mett.

Loxoscaphe gibberosa (G. Forst.) T. Moore.

Terrestrial.

Fosberg 61050 (віsн): Maatea Valley; Florence 4803 (BISH): Site 1; Florence 4875 (BISH; us): Maatea Valley. 
Asplenium polyodon $\mathrm{G}$. Forst.

Asplenium adiantoides (L.) C. Chr. var. polyodon (G. Forst.) C. Chr.

Epiphytic or lithophytic, found in tree forks, at times with Asplenium australasicum, as well as on logs and rocks.

Smith 149 (Uc): Site 1, in Pandanus areas.

Asplenium tenerum G. Forst.

Asplenium elongatum $\mathrm{Sw}$.

Lithophytic, rain forest, generally near creeks.

Grant 5382 (Uc): Site 1; Sánchez B. 174 (Uc): Site 2 .

\section{BLECHNACEAE}

\section{Blechnum orientale L.}

Terrestrial at middle to high elevations, usually found in exposed, drier areas, often in colonies.

Mishler 1 (Uc): Site 6, with Dicranopteris linearis; Sánchez B. 156 (uc): Site 2.

\section{Blechnum raiateense J. W. Moore}

Terrestrial.

Grant 5392 (Uc): Site 1.

\section{Cyatheaceae}

Alsopbila tabitensis Brack.

Cyathea affinis (G. Forst.) Sw.; Cyatbea tabitensis (Brack.) Copel.; Holttum (1964).

Terrestrial at high elevations, tree fern to $10 \mathrm{~m}$, in rain forests and cloud forests; extirpated from some previously known localities on Moorea.

Grant 5393 (UC): Site 1; Smith 161 (UC): Site 1.

Sphaeropteris medullaris (G. Forst.) Bernh. Cyatbea medullaris (G. Forst.) Sw.; Cyatbea societarum Baker; Holttum (1964).

Terrestrial at high elevations, in rain forests and cloud forests; extirpated from some previously known localities on Moorea.

Grant 5394 (Uc): Site 1.

\section{Davalliaceae}

Artbropteris sp.

Holttum (1966b).
Epiphytic in rain forests, growing on smaller trees.

Hinkle 93 (Uc): Site 2, on Three Coconuts trail.

Most likely Artbropteris palisotii (Desv.) Alston or Arthropteris repens (Brack.) C. Chr.; collections are sterile.

Davallia denticulata (Burm. f.) Mett. ex Kuhn var. elata (G. Forst.) Mett. ex Kuhn

Davallia epipbylla (G. Forst.) Spreng.; Nooteboom (1994).

Terrestrial at low to middle elevations, in forest understory near streams and/or in rocky areas.

Smitb 167 (uc): Site 1; Sánchez B. 163 (uc): Site 2.

Davallia solida (G. Forst.) Sw. var. solida Nooteboom (1994).

Epiphytic or lithophytic at all elevations, usually in rain forests.

Smith 166B/167 (Uc): Site 1; Sánchez B. 131 (Uc): Site 3; Sánchez B. 153 (Uc): Site 7; Hinkle 104 (Uc): Site 2, on Three Coconuts trail.

Pachypleuria pectinata (Sm.) C. Presl Davallia pectinata Sm.; Humata banksii Alston; Humata pectinata (Sm.) Desv.

Epiphytic or lithophytic, climbing on trees in rain forests.

Smith 10 (UC): Site 8; Sánchez B. 160 (UC): Site 2.

This species is frequently treated in $D a$ vallia or Humata; we prefer to adopt the taxonomy presented by Kato (1985), recognizing Pacbypleuria, rather than lumping most davallioids in Davallia, a taxonomy favored by Nooteboom (1994).

\section{DenNSTAEDTIACEAE}

Hypolepis tenuifolia (G. Forst.) Bernh. Lonchitis tenuifolia G. Forst.; Brownsey (1987). Terrestrial, in disturbed areas near streams, usually in clearings.

Grant 5390 (uc): Site 1.

Lindsaea propinqua Hook.

Lindsaea raiateensis J. W. Moore; Kramer (1970). 
Terrestrial in forest understory.

Not seen by us, but reported by Jacques Florence (in litt., 2002).

\section{Microlepia scaberula Mett.}

Terrestrial in forest understory.

Quayle 144 (Uc): Site 1.

\section{DRYOPTERIDACEAE}

Arachniodes aristata (G. Forst.) Tindale Prickly shield fern

Polysticbum aristatum (G. Forst.) C. Presl.

Terrestrial, in moist areas in forest understory and among boulders.

Sáncbez B. 158 (Uc): Site 2.

Bolbitis lonchopbora (Fée) C. Chr.

Campium lonchophorum (Fée) Copel.; Hennipman (1977).

Terrestrial, damp areas near streams in small valleys.

Smith 30 (Uc): Faatoai Valley; Sánchez $B$. 126 (Uc): Site 3; Sánchez B. 140 (Uc): Site 4; Hinkle 102 (Uc): Site 2, on Three Coconuts trail.

Ctenitis sciaphila (Maxon) Ching var. sciapbila Dryopteris sciapbila Maxon.

Terrestrial, in forest understory.

Grant 5395 (uc): Site 1; Sánchez B. 145 (Uc): Site 4; Sánchez B. 172 (UC): Site 2.

Diplazium ellipticum (Copel.) C. Chr. Atbyrium ellipticum Copel.

Terrestrial in forest understory.

Smith 119 (us): Faatoai Valley (specimen not seen); also reported by Fosberg and Stoddart (1996).

Diplazium grantii (Copel.) C. Chr. Athyrium grantii Copel.; Copeland (1932).

Terrestrial in forest understory.

Smith 120 (Us): Faatoai Valley (specimen not seen); also collected by Jacques Florence (in litt., 2002) and reported by Fosberg and Stoddart (1996).

\section{Diplazium barpeodes T. Moore}

Asplenium polyanthes Sol. ex Baker; Atbyrium polyanthes (Sol. ex Baker) Copel.; Diplazium polyanthes (Sol. ex Baker) C. Chr.
Terrestrial in forest understory.

Sáncbez B. 144 (Uc): Site 4; Sáncbez B. 181 (UC): Site 2.

\section{Lomagramma tabitensis Holttum}

Lomagramma lomarioides (Blume) J. Sm. sensu Copel., 1932. Holttum (1966a).

Terrestrial and climbing trees in forests. Grant 5397 (Uc): Site 1.

Lomariopsis brackenridgei Carruth.

Lomariopsis setchellii (Maxon) Holttum; Stenocblaena setchellii Maxon; Holttum (1966a).

Terrestrial and climbing trees in forest understory, in rocky, shaded areas.

Quayle 146 (Uc): Site 1; Sánchez B. 128 (uc): Site 3; Sánchez B. 150 (uc): Site 7; Hinkle 91 (Uc): Site 2, on Three Coconuts trail.

Tectaria tabitensis Maxon

Aspidium lessonii Bory; Tectaria lessonii (Bory)

Holttum, ined.; Holttum (1985).

Terrestrial, in forest understory.

Grant 5369 (uc): Site 1; Sánchez B. 149 (Uc): Site 7; Sánchez B. 171 (uc): Site 2.

Teratopbyllum wilkesianum (Brack.) Holttum Lomagramma wilkesiana (Brack.) Copel.; Holttum (1966a).

Terrestrial and climbing trees, sometimes in open areas.

Sánchez B. 168 (uc): Site 9.

\section{Gleicheniaceae}

Dicranopteris linearis (Burm. f.) Underw. var. linearis

Gleichenia linearis (Burm. f.) C. B. Clarke.

Terrestrial, thicket-forming, aggressive weed in dry, open, disturbed areas at all elevations; will completely colonize fire scars, growing in dense thickets up to $3 \mathrm{~m}$ tall, often in very hot, exposed ridges, where it forms the dominant ground cover; extensive use in decorating for festivals.

Smith 108 (Uc); Sánchez B. 159 (uc): Site 2.

\section{Grammitidaceae}

Ctenopteris blecbnoides (Grev.) W. $H$. Wagner \& Grether

Grammitis blecbnoides Grev.; Polypodium blecbnoides (Grev.) Hook. 

forests.

Lithophytic or epiphytic in moist rain

Smith 176 (Uc): Site 1; Hinkle 81 (uc): Site 1, Mt. Mou'aputa trail.

Ctenopteris purpurascens (Nadeaud) Copel. Epiphytic in moist rain forests.

Florence 8358 (BISH): Site 1, valley between summits.

Prosaptia subnuda (Mett.) Copel. Polypodium subnudum Mett.

Epiphytic in moist rain forests.

Grant 5400 (UC): Site 1.

Hymenophyllaceae

(Classification following Morton [1968])

\section{Trichomanes (Crepidomanes) bipunctatum}

Poir.

Lithophytic or, less commonly, epiphytic in rain forest understory, highly branched, sometimes growing with Tricbomanes bumile.

Grant 5376 (UC); Sáncbez B. 135, 136, 165, 178 (Uc): Site 2; Hinkle 92 (uc): Site 2, on Three Coconuts trail.

\section{Trichomanes (Pacbycbaetum) dentatum \\ Bosch}

Terrestrial in rain forest understory.

Florence 4778 (в ISH): Mt. Mou'aputa.

Trichomanes (Crepidium) bumile G. Forst.

Epiphytic or lithophytic in rain forest near streams, highly branched.

Grant 5371 (Uc): Site 1 [specimen contains Trichomanes tabitensis]; Sáncbez B. 137, 177 (uc): Site 2.

Trichomanes (Pleuromanes) pallidum Blume Epiphytic in rain forest understory.

Not seen by us, but reported by Jacques Florence (in litt., 2002); also reported for Moorea by Fosberg and Stoddart (1996).

Trichomanes (Callistopteris) societense J. W. Moore

Trichomanes polyanthos (Hook.) Hook., non

Sw.; Hymenopbyllum polyanthos Hook., non Sw.

Terrestrial in rain forest understory.
Not seen by us, but reported by Jacques Florence (in litt., 2002); also reported for Moorea by Fosberg and Stoddart (1996).

Closely related to, and possibly not distinct from, T. apiifolium C. Presl.

Trichomanes (Microgonium) tabitense

Nadeaud

Microgonium omphalodes Vieill.; Trichomanes ompbalodes (Vieill.) C. Chr.

Epiphytic or lithophytic on trees and wet rocks in rain forests.

Sánchez B. 164 (Uc): Site 2.

\section{LYCOPODIACEAE}

Huperzia phlegmaria (L.) Rothm. Coarse tassel fern, Common tassel fern Lycopodium pblegmaria L.

Epiphytic, rarely lithophytic or terrestrial, pendant.

Florence 2112 (вISH; Us): Maatea Valley; Gagne \& Montgomery 2391 (в ISH): Site 2.

Lycopodiella cernua (L.) Pic. Serm.

Lycopodium cernuum $\mathrm{L}$.

Terrestrial at high elevations, erect clubmoss with nodding strobili, found in open dry to moist areas, or on forest borders in understory.

Sánchez B. 161 (Uc): Site 2.

\section{Marattiaceae}

Angiopteris evecta (G. Forst.) Hoffm.

Terrestrial at middle to high elevations, fronds 3 or $4 \mathrm{~m}$, widespread in damp areas near streams in valleys.

Grant 5370 (vc): Site 1; 7. F. Murray 7r. 186 (Uc): Hotutea; Sáncbez B. 157 (uc): Site 2.

All Angiopteris from Moorea appear to be Angiopteris evecta and not $A$. longifolia Grev. \& Hook., sometimes attributed to the Society Islands.

\section{Marattia salicina Sm.}

Terrestrial at high elevations, in wet valleys.

Smith 172 (Uc): Site 1.

Marattia cincta Copel. and $M$. grantii Copel., types from Tahiti, appear to be indistinct from $M$. salicina, which has priority. 


\section{Marsileaceae}

Marsilea polycarpa Hook. \& Grev.

Johnson (1986).

Aquatic or semiaquatic fern with cloverlike leaves, in shallow water and very moist areas.

Grant 5412 (Uc): Site 1.

\section{NePhrolepidaceaE}

Nephrolepis cordifolia (L.) C. Presl Fishbone fern, Herringbone fern, Sword fern

Terrestrial in open areas, near sea level. Sánchez B. 155 (Uc): Site 7.

\section{Nephrolepis exaltata (L.) Schott}

Terrestrial.

Sáncbez B. 143 (uc): Site 4.

Material identified as Nephrolepis biserrata from Moorea (and perhaps the entire Society Archipelago) appears to be misdetermined specimens of $N$. exaltata or $N$. birsutula. Revision of this genus is badly needed.

\section{Nephrolepis hirsutula (G. Forst.) C. Presl}

Terrestrial or epiphytic, fronds to ca. $1 \mathrm{~m}$, common at all elevations in forested areas.

Fosberg 60970A (в гон): Site 2; Smith 85 (UC): Opunohu Valley; Smith 164 (Uc): Site 1; Sánchez B. 154 (uc): Site 7; Hinkle 89, 111 (uc): Site 5.

The widespread and often-used name $N$. multiflora (Roxb.) F. M. Jarrett ex C. V. Morton is probably synonymous with this species (Bell in McCarthy 1998).

\section{Ophioglossaceae}

Ophioglossum pendulum L. Ribbon fern Opbioderma pendula (L.) C. Presl.

Epiphytic or on fallen logs, at middle to high elevations epiphyte, pendant on forest trees, frequently with Asplenium australasicum.

Smith 53 (uc): Maramu Valley.

\section{Ophioglossum reticulatum $\mathrm{L}$.}

Terrestrial at low elevations, in light forest or open areas near water sources.

Gartner 1994 Class Collection (uc): No collection information available.

\section{Polypodiaceae}

Belvisia spicata (L.f.) Mirb. ex Copel. Acrostichum spicatum L.f.; Belvisia revoluta (Blume) Copel.; Hymenolepis revoluta Blume; Hovenkamp and Franken (1993).

Epiphyte or lithophyte in rain forests, usually bordering streams.

Grant 5384 (UC): Site 1; Hinkle 94, 95 (Uc): Site 2, on Three Coconuts trail.

Microsorum commutatum (Blume) Copel.

Microsorum sylvaticum (Brack.) Copel.; Pbymatodes commutata (Blume) Ching; Pbymatosorus commutatus (Blume) Pic. Serm.; Polypodium expansum Baker; Polypodium polynesicum C. Chr.; Polypodium sylvaticum (Brack.) Mett.; Polypodium vitiense Baker; Nooteboom (1997).

Epiphytic or terrestrial in forest understory.

Smith 89 (Uc): Site 8; Sánchez B. 175 (Uc): Site 2; Hinkle 90 (Uc): Site 8; Hinkle 97 (uc): Site 2, on Three Coconuts trail.

For purpose of our checklist, Pbymatosorus is treated as a synonym of Microsorum in accordance with Nooteboom (1997) and contrary to Bosman (1991). The distinctions between these two genera are still uncertain, and additional study is needed. Preliminary molecular work on this family points out the need for revised circumscription of many Old World genera of Polypodiaceae (Smith et al. 2000; Schneider, et al., 2003, unpubl. data (?)

Microsorum grossum (Langsd. \& Fisch.) S. B. Andrews

Phymatosorus grossus (Langsd. \& Fisch.) Brownlie.

Terrestrial or lithophytic, at all elevations in exposed areas or under light tree cover; also found on motu.

Smith 94 (Uc): Small coral islands of the northwest coast [Motu Fareone and Motu Tiahura]; Sánchez B. 170 (Uc): Site 2; Hinkle 106, 107 (Uc): Site 8, Lycée Agricole.

Nooteboom (1997) synonymized this species under M. scolopendria (Burm. f.) Copel., but we believe that there is ample evidence for keeping them as distinct species. All re- 
ports of $M$. scolopendria (Burm. f.) Copel. for French Polynesia are referable to $M$. grossum (Langsd. \& Fisch.) S. B. Andrews.

Microsorum × maximum (Brack.) Copel., pro sp.

$=$ Microsorum punctatum $\times$ Microsorum grossum; Polypodium maximum (Brack.) Hook.; Nooteboom (1997).

Terrestrial or lithophytic at low elevations, coastal areas. Rare hybrid with irregular blades.

Sánchez B. 152 (Uc): Site 1.

Microsorum membranifolium (R. Br.) Ching Polypodium membranifolium R. Br.; Pbymatosorus nigrescens (Blume) Pic. Serm.; Nooteboom (1997).

Epiphytic or lithophytic in forest understory.

Grant 5402 (віSн): Site 1.

\section{Microsorum punctatum (L.) Copel.}

Polypodium punctatum L.; Nooteboom (1997).

Terrestrial, lithophytic, or rarely epiphytic at low elevations, in xeric coastal areas, frequently in sandy soil in coastal forest.

Smith 86 (UC): Site 8; Sánchez B. 151 (Uc): Site 7.

\section{Pyrrosia serpens (G. Forst.) Ching}

Cyclophorus blepharolepis C. Chr;; Pyrrosia blepbarolepis (C. Chr.) Ching; Hovenkamp (1986).

Epiphytic or lithophytic.

Grant 5385 (Uc): Site 1; Sánchez B. 125

(UC): Site 3; Sánchez B. 142 (UC): Site 4.

\section{Psilotaceae}

Psilotum nudum (L.) P. Beauv. Skeleton fork fern

Epiphytic or terrestrial, all elevations.

Smith 84 (UC): Site 8; Grant 5360 (Uc):

Nuurua; Grant 5381 (uc): Site 1.

Tmesipteris gracilis Chinnock, n. sp.

Epiphytic, high elevations, nearly always on tree ferns.

Grant 5399 (Uc): Site 1.
All collections identified as Tmesipteris tannensis for the Society and Marquesas Islands are referable to Tmesipteris gracilis Chinnock. See Appendix for description (Chinnock 1975, 1976, Braithwaite 1986). Several tree fern (family Cyatheaceae) populations on Moorea have been extirpated in recent years, and the preferred habitat of this species has become threatened on Moorea.

\section{Pteridaceae}

Acrostichum aureum L. Golden mangrove fern

Terrestrial at low elevations, fronds to 4 $\mathrm{m}$, in open, moist, muddy, and/or swampy areas, among mangroves, and on coastal cliffs.

Smitb 110 (uc): Site 8; Sánchez B. 169 (Uc): Site 9.

Adiantum bispidulum Sw. Rough maidenhair fern

Terrestrial, rarely lithophytic on damp rocks in very shady places in understory, near streams and in moist areas.

Smith 50 (uc): Tehaoa Valley; Sánchez $B$. 141 (Uc): Site 4; Sánchez B. 148 (Uc): Site 7.

\section{Adiantum raddianum C. Presl}

Terrestrial or lithophytic in forest understory. Native to South America, naturalized on Moorea.

Sáncbez B. 147 (Uc): Site 7; Hinkle 103 (uc): Site 2, on Three Coconuts trail.

\section{Adiantum trapeziforme $\mathrm{L}$.}

Terrestrial at middle to high elevations, in exposed, dry to moist areas. Native to Mexico and Central America, naturalized on Moorea.

Sánchez B. 124 (Uc): Site 3; Hinkle 105 (uc): Site 2, on Three Coconuts trail.

\section{Pityrogramma calomelanos (L.) Link}

Terrestrial at low to middle elevations, in rocky disturbed areas, forest margins, plantations. Native to the Neotropics.

Sánchez B. 134 (Uc): Site 2.

Pteris comans G. Forst. Netted brake fern

Terrestrial, fronds to $1 \mathrm{~m}$, in shaded rain forests near streams, in rocky soils.

Quayle 145 (Uc): Site 1. 
Pteris tripartita Sw. Giant brake fern, Lacy brake fern

Terrestrial, fronds to $1 \mathrm{~m}$, in rain forests near streams.

Smith 131 (Uc): Faatoai Valley, near dam; Sánchez B. 146 (Uc): Site 7; Sánchez B. 176 (UC): Site 2.

\section{SChizAEACEAE}

Lygodium reticulatum Schkuhr Climbing fern

Twining vine at middle to high elevations, in rain forests, frequently in disturbed sites.

Smith 14 (Uc): Site 8; Sáncbez B. 130 (Uc): Site 3; Hinkle 96, 100 (vc): Site 2, on Three Coconuts trail.

Schizaea dichotoma (L.) Sm. Fan fern

Lopbidium dichotomum (L.) Maxon.

Terrestrial at middle to high elevations, in various habitats, wet to dry, in forests and in open areas, uncommon.

Smith 9 (Uc): Site 8, under Hibiscus tiliaceus; Sánchez B. 129 (Uc): Site 3.

\section{Selaginellaceae}

\section{Selaginella banksii Alston}

Terrestrial in forests.

Grant 5391 (Uc): Site 1.

\section{Thelypteridaceae}

\section{Macrotbelypteris polypodioides}

Holttum Taiwanese tree fern

Dryopteris leucolepis (C. Presl) Maxon; Holttum $(1969,1977)$.

Terrestrial in open areas.

Grant 5374 (Uc): Site 1; Sánchez B. 167 (Uc): Site 8 .

Plesioneuron attenuatum (Brack.) Holttum

Dryopteris brackenridgei (Mett.) Kuntze; Thelypteris brackenridgei (Mett.) C. F. Reed; Holttum (1977).

Terrestrial or lithophytic in forest understory.

Grant 5401 (Uc): Site 1; Sánchez B. 173, 180 (Uc): Site 2.

Sphaerostephanos invisus (G. Forst.) Holttum Dryopteris invisa (G. Forst.) Kuntze; Tbely- pteris forsteri C. V. Morton; Holttum (1977).

Terrestrial in forest understory.

Sánchez B. 166 (Uc): Site 5; Hinkle 99 (Uc):

Site 5.

\section{Spbaerostephanos subpectinatus (Copel.)} Holttum

Dryopteris subpectinata Copel.; Thelypteris subpectinata (Copel.) C. F. Reed; Holttum (1977).

Terrestrial in forest understory.

Sánchez B. 132 (UC): Site 2.

\section{VitTARIACEAE}

Antrophyum plantagineum (Cav.) Kaulf. Antropbyum lessonii Bory; Antropbyum plantagineum (Cav.) Kaulf. var. lessonii (Bory) Hook. \& Arn.

Epiphytic or lithophytic, in damp areas, usually under substantial tree cover.

McKee 3086 (uc): on Inocarpus; Smith 47 (Uc): Tehaoa Valley; Sánchez B. 133 (Uc): Site 2; Hinkle 88 (UC): Site 2.

Antropbyum reticulatum (G. Forst.) Kaulf. Hemionitis reticulata $\mathrm{G}$. Forst.

Epiphytic or lithophytic, in damp areas, usually under substantial tree cover.

Grant 5379 (Uc): Site 1; Fosberg 61040a (us): Maatea Valley; Sánchez B. 139 (uc): Site 4; Sáncbez B. 179 (UC): Site 2.

There are many reports of $A$. callifolium Blume (type from Java) from the Society Islands, but collections identified as this in herbaria are all referable to $A$. reticulatum (type from Tahiti), the older name. In any case, $A$. callifolium is dubiously distinct.

Haplopteris elongata (Sw.) E. H. Crane Tape fern

Vittaria elongata $\mathrm{Sw}$.

Epiphytic or lithophytic; grasslike fern, mostly on roots of other larger epiphytes, on fallen logs, or on rocks.

Sáncbez B. 138 (Uc): Site 4.

\section{Other Species Reported from Moorea}

The following species have all been reported from Moorea and are known to be on other 
islands in the Society Archipelago, but they cannot be verified with collections available to us.

Cbristella dentata (Forssk.) Brownsey \& Jermy Dryopteris dentata (Forsk.) C. Chr.; Thelypteris dentata (Forssk.) E. P. St. John.

Reported for Moorea by Copeland (1932). Widely naturalized in the Neotropics, as well as on many islands in the Pacific (e.g., Hawai'i, Tahiti).

Elapboglossum nadeaudii Krajina, ined.

Elapboglossum gorgoneum sensu auctt., not (Kaulf.) Brack.; Acrostichum gorgoneum Kaulf. sensu auctt., not Kaulf.

Reported for Moorea by Drake del Castillo (1893); known from Tahiti, Bora Bora.

Lindsaea repens (Bory) Thwaites var. marquesensis E. D. Br.

Reported for Moorea by Robertson (1952); known from 'Tahiti, Bora Bora.

Macrotbelypteris torresiana (Gaudich.) Ching

Dryopteris setigera (Blume) Kuntze; Lastrea torresiana (Gaudich.) T. Moore; Thelypteris torresiana (Gaudich.) Alston.

Reported for Moorea by Robertson (1952) and Fosberg and Stoddart (1996); known from Tahiti, Bora Bora.

Specimens so identified may be errors for Macrothelypteris polypodioides.

\section{Nepbrolepis biserrata (Sw.) Schott}

Reported for Moorea by Fosberg and Stoddart (1996); known from Tahiti, Mehetia, Huahine, Tupai, Bora Bora.

Material identified as Nephrolepis biserrata from Moorea (and perhaps the entire Society Archipelago) appears to be misdetermined specimens of $N$. exaltata and $N$. birsutula. Fosberg and Stoddart's (1996) report may be equally inaccurate.

Prosaptia contigua (G. Forst.) C. Presl

Davallia contigua $\mathrm{Sw}$.; Ctenopteris contigua (G.

Forst.) Holttum; Tricbomanes contiguum $\mathrm{G}$.

Forst.

Reported for Moorea by Drake del Castillo (1893); known from Tahiti, Huahine.
Sphenomeris chinensis (L.) Maxon

Davallia cbinensis Sw.

Reported for Moorea by Drake del Castillo (1893); known from Tahiti, Raiatea, Bora Bora, Tahaa.

Extremely widespread and common in the Pacific.

Trichomanes (Macroglena) asae-grayi Bosch

Reported for Moorea by Fosberg and Stoddart (1996); known from Tahiti.

Trichomanes (Pacbycbaetum) caudatum Brack.

Reported for Moorea by Robertson (1952) and Fosberg and Stoddart (1996); known from Tahiti, Bora Bora.

\section{Species to Be Expected}

We include here selected species present on Tahiti and/or other Society Islands. These are mostly species that are also widely distributed in Polynesia, at elevations and in habitats represented on Moorea.

Asplenium laserpitiifolium Lam.: Tahiti.

Blechnum vulcanicum (Blume) Kuhn: Tahiti, Tahaa, Huahine, Raiatea.

Christella parasitica (L.) Léveillé: Tahiti.

Cyclosorus interruptus (Willd.) H. Itô: Tahiti.

Deparia confluens (Kunze) M. Kato: Tahiti.

Deparia petersenii (Kunze) M. Kato subsp. congrua (Brack.) M. Kato: Tahiti, Raiatea.

Diplopterygium longissimum (Blume) Nakai: Tahiti, Huahine.

Doryopteris concolor (Langsd. \& Fisch.) Kuhn: Tahiti, Bora Bora, also collected on Tahiti on second Cook expedition.

Elapboglossum societarum Copel.: Tahaa, Huahine.

Grammitis tracbycarpa (Mett. ex Kuhn) Copel.: Tahiti, Tahaa, Huahine, Raiatea.

Huperzia squarrosa (G. Forst.) Trevis.: Tahiti. Hymenopbyllum (Mecodium) polyantbos (Sw.) Sw.: Tahiti, Bora Bora.

Pneumatopteris costata (Brack.) Holttum: Tahiti.

Psilotum complanatum Sw.: Tahit, Tahaa, Raiatea, Bora Bora.

Selaginella laxa Spring: Tahit, Bora Bora.

Selaginella setchellii $\mathrm{O}$. C. Schmidt: Tahiti.

Selliguea plantaginea Brack.: Tahit, Huahine. 
Tectaria decurrens (C. Presl) Copel.: Tahiti, Raiatea.

Trichomanes (Vandenboschia) maximum Blume: Tahiti, Huahine, Raiatea.

\section{ACKNOWLEDGMENTS}

We thank the following for their assistance or advice in the preparation of this paper: Robert Chinnock for his Appendix on Tmesipteris gracilis; Barbara Parris for discussion and help on Grammitidaceae; Patricia Sánchez Baracaldo for access to her collections; Brent Mishler and John Game for advice and suggestions on the manuscript; Jacques Florence for sending us notes on his collections; and Greg McKee (Us), Chris Puttock (BIsH), and Peter Edwards (k) for facilitating loans and searching for collections of several taxa in their herbaria.

\section{Literature Cited}

Bosman, M. T. M. 1991. A monograph of the fern genus Microsorum (Polypodiaceae). Leiden Bot. Ser. 14:1-161.

Braithwaite, A. F. 1986. Tmesipteris in Vanuatu (New Hebrides). Fern Gaz. 13:87-96.

Brown, F. B. H. 1931-1935. Flora of southeastern Polynesia. Bernice P. Bishop Mus. Bull. 84:1-194, and 130:1-386.

Brownsey, P. 1987. A review of the fern genus Hypolepis (Dennstaedtiaceae) in the Malesian and Pacific regions. Blumea 32:227-276.

Chinnock, R. J. 1975. The New Zealand species of Tmesipteris (Psilotaceae). N. Z. J. Bot. 13:743-768.

- 1976. The identification, typification and origin of Tmesipteris tannensis (Psilotaceae). Taxon 25:115-121.

Copeland, E. B. 1932. Pteridophytes of the Society Islands. Bernice P. Bishop Mus. Bull. 93:1-86.

Drake del Castillo, E. 1893. Flore de la Polynésie Française. Masson, Paris.

Fosberg, F. R., and D. R. Stoddart, eds. 1996. Interim checklist of the flowering plants and ferns of the Society Islands. University of California at Berkeley, Richard B. Gump South Pacific Biological Research Station, Moorea, P. F. Privately published xerocopy in University of California Herbarium library.

Grant, D. 1986. Martin Grant's botanical journals: Society Islands (1930), Hawaii (1934), Colombia (1944-5). Privately published by the collector's wife; xerocopy in University of California Herbarium library.

Grant, M. L. 1936. Flora of the Society Islands. Dicotyledones: Sympetalae. Part I. Ph.D. diss., University of Minnesota, Twin Cities.

Grant, M. L., F. R. Fosberg, and H. M. Smith. 1974. Partial flora of the Society Islands: Ericaceae to Apocynaceae. Smithson. Contrib. Bot. 17.

Gulamhussein, S. 2000. Distribution and desiccation tolerance of the filmy fern genus Trichomanes in two stream valleys on Moorea, French Polynesia. Biol. Geomorphol. Trop. Isl. 10:76-85.

Hennipman, E. 1977. A monograph of the fern genus Bolbitis (Lomariopsidaceae). Leiden Bot. Ser. 2:1-331.

Holttum, R. E. 1964. The tree-ferns of the genus Cyathea in Australasia and the $\mathrm{Pa}$ cific. Blumea 12:241-274.

- 1966a. The genera Lomariopsis, Teratopbyllum, and Lomagramma in the islands of the Pacific and Australia. Blumea 14:215-223.

1966b. The genus Artbropteris J. Sm. in Malesia. Blumea 14:225-229.

- 1969. Studies in the family Thelypteridaceae. The genera Pbegopteris, Pseudophegopteris, and Macrotbelypteris. Blumea 17:5-32.

17. 1974. Asplenium Linn., sect. Thamnopteris Presl. Gard. Bull. Straits Settlem. 27:143-154.

27. 1977. The family Thelypteridaceae in the Pacific and Australia. Allertonia 1:169-234.

1985. Studies in the fern genera allied to Tectaria Cav. IV. The genus Ctenitis in Asia, Malesia, and the western Pacific. Blumea 31:1-38.

Hovenkamp, P. 1986. A monograph of the fern genus Pyrrosia (Polypodiaceae). Leiden Bot. Ser. 9:1-280.

Hovenkamp, P., and N. A. P. Franken. 1993. An account of the fern genus Belvisia Mirbel (Polypodiaceae). Blumea 37:511-527. 
Johnson, D. M. 1986. Systematics of the New World species of Marsilea (Marsileaceae). Syst. Bot. Monogr. 11:1-87.

Kato, M. 1985. A systematic study of the genera of the fern family Davalliaceae. $J$. Fac. Sci. Univ. Tokyo, Sect. III, Bot. 13:553-573.

Kramer, K. U. 1970. The lindsaeoid ferns of the Old World. V. The smaller Pacific islands. Blumea 18:157-194.

Maxon, W. R. 1924. Report upon a collection of ferns from Tahiti. Univ. Calif. Publ. Bot. 12:17-44.

McCarthy, P. M., vol. ed. 1998. Flora of Australia. Vol. 48. Ferns, gymnosperms, and allied groups. ABRS/CSIRO Australia, Melbourne.

Morton, C. V. 1968. The genera, subgenera, and sections of the Hymenophyllaceae. Contrib. U.S. Natl. Herb. 38:153-214.

Nooteboom, H. P. 1994. Notes on Davalliaceae II. A revision of the genus Davallia. Blumea 39:151-214.

- 1997. The microsoroid ferns (Polypodiaceae). Blumea 42:261-395.

Robertson, R. 1952. Catalogue des plantes vasculaires de la Polynésie Française. Bull. Soc. Etud. Ocean. nos. 98, 99, 8 (9-10): 371-406.

Smith, A. R., H. Schneider, B. S. Parris, C. H. Haufler, T. A. Ranker, J. P. Therrien, and J. M. O. Geiger. 2000. Phylogeny of Grammitidaceae and Polypodiaceae inferred from two large data sets: $r b c L$ and morphology. Am. J. Bot. 87 (6): 97.

\section{Appendix}

A New Species of the Genus Tmesipteris in the Society Islands and Marquesas Islands

\section{Robert 7. Cbinnock}

State Herbarium of South Australia, Plant Biodiversity Centre, Hackney Road, Hackney, S.A. 5069, Australia (Postal address: P.O. Box 2732, Kent Town, S.A. 5071; E-mail: Chinnock.Bob@saugov.sa.gov.au)

\section{Tmesipteris gracilis Chinnock, n. sp.}

Plantae epiphyticae surculis aeriis pendulis, $9-39 \mathrm{~cm}$ longis; foliis sterilibus sessilibus uno plano-complanatis, anguste ad late oblique lanceolatis saepe falcatis, mucronatis, $8-26 \mathrm{~mm}$ longis, $2-5 \mathrm{~mm}$ latis, subcoriaceis rigidis; foliis sporogenis spiralibus dispositis plerumque ad basim surculi aerii petiolatis; synangio testiculato, $2.5-4 \mathrm{~mm}$ longo, 1-2 mm lato; sporangiis obtusis.

Type: Tahiti: Pare, Fautaua, below Diadem, $2970 \mathrm{ft}$, 13.V.1930, M. L. Grant 3564; holotype: в Isн 42504; isotypes: B, MO, NY, Uc, Us, w.

Plants epiphytic. Aerial shoots, simple, pendulous, (9-) $18-24(-39) \mathrm{cm}$ long, terminating in a leaf $1-2$ times length of longest lateral ones. Sterile leaves distichously arranged but occasionally with one or two directed in another plane, 2-5 per $\mathrm{cm}$ of shoot, sessile, narrowly to broadly and obliquely lanceolate, often falcate especially in distal part of aerial shoot, (8-) 17-21 (-26) $\mathrm{mm}$ long, 2-5 mm wide, 4-5 times as long as broad, one surface shiny, lacking stomata, other surface possessing stomata, dull; subcoriaceous, firm, mucronate, mucro to $1 \mathrm{~mm}$ long. Sporogenous leaves spirally arranged, 3-6 per $\mathrm{cm}$ of shoot, occurring normally in proximal half of aerial shoot, petiolate, petiole $1-3 \mathrm{~mm}$ long, bifid, lamina of both portions similar to sterile leaves. Synangia small, testiculate, $2.5-4 \mathrm{~mm}$ long, 1-2 $\mathrm{mm}$ wide, 1-1.8 $\mathrm{mm}$ high at point of attachment, sporangia equal or slightly unequal, obtuse.

Tmesipteris gracilis is widespread throughout the Society Islands and Marquesas Islands, where it grows at higher elevations between 700 and $1350 \mathrm{~m}$, rarely as low as $400 \mathrm{~m}$ (Papara, Tahiti). It commonly occurs in wet forest on the trunks of tree ferns (Cyatbea spp.) but occasionally also on branches of trees and shrubs among mosses.

Following Chinnock (1975), $T$. gracilis belongs to the Lanceolata Group of species. The aerial shoot is of limited growth and develops over one season, terminating in a leaf similar in size to, or longer than, the lateral ones. The synangium is of the testiculate type (Chinnock 1975) with the sporangia globular to oblong, similar in size or the proximal one smaller.

Tmesipteris gracilis is closely related to T. norfolkensis (Norfolk Island) and T. lanceolata (New Zealand and New Caledonia), sharing with these species sterile leaves flattened into one plane and generally having the sporebearing leaves restricted to the lower half of the aerial shoot. It differs in having narrower leaves and a distinctly terminal falcate leaf and frequently falcate lateral leaves in the distal part of the shoot.

The directors of the following herbaria are thanked for loans of Tmesipteris to $A D$ or for providing access to collections in their institutions: BISH, BM, BRI, G, GH, LAE, MO, P, UPS, US, W, WELT. 